\title{
HUBUNGAN KADAR IL-8 DAN IL-4 PADA ANAK DENGAN STATUS EPILEPTIKUS
}

\author{
Abstrak \\ Haykal Affandiं ${ }^{\star 凶}$, Hidayat Sujuti ${ }^{\star \star}$, Happy Kurnia Permatasari ${ }^{\star \star}$, Masdar Muid ${ }^{\star \star \star}$
}

\begin{abstract}
Status epileptikus merupakan suatu kegawatan di bidang neurologi yang memerlukan diagnosis dan terapi yang sesuai. Ketidakseimbangan sitokin proinflamasi dan antiinflamasi bisa menyebabkan kejang yang berlangsung lama. Sitokin proinflamasi dapat mengaktivasi kaskade signaling dan merusak sawar darah-otak yang mengawali mekanisme terjadinya kejang. Penelitian ini ingin mengetahui perbedaan kadar IL-8 dan IL-4 pada anak status epileptikus, kejang tanpa status epileptikus, dan demam tanpa kejang sehingga bisa dijadikan prediktor kejadian status epileptikus. Desain penelitian adalah cross sectional dengan 30 sampel yang terdiri dari 10 anak status epileptikus, 10 anak kejang tanpa status epileptikus, dan 10 anak demam tanpa kejang. Pengukuran IL-8 dan IL-4 menggunakan metode ELISA. Analisis data menggunakan uji one way ANOVA dan korelasi Spearman dengan menggunakan SPSS-23. Didapatkan kadar IL-8 $(p=0,000)$ berbeda signifikan dan kadar IL-4 tidak berbeda signifikan $(p=0,818)$ pada status epileptikus, kejang tanpa status epileptikus dan demam tanpa kejang. Namun, rasio IL-4/1L-8 menunjukkan perbedaan yang signifikan $(p=0,000)$ di antara kelompok. Dapat disimpulkan ada hubungan antara kadar IL-8, rasio IL-4/L-8 dengan status epileptikus, namun tidak ada hubungan yang signifikan pada kadar IL-4.
\end{abstract}

Kata kunci: kadar IL-8, kadar IL-4, status epileptikus.

\section{RELATIONSHIP BETWEEN IL-8 AND IL-4 LEVELS IN CHILDREN WITH STATUS EPILEPTICUS}

\begin{abstract}
Status epilepticus is a neurological emergency which requires prompt diagnosis and treatment. Imbalance between proinflammatory and antiinflammatory cytokines can cause prolonged seizure. Proinflammatory cytokines may activate signaling cascade and disrupts blood brain barrier which initiates seizure. The research aim was to determine the changes of IL-8 and IL-4 levels in children with status epilepticus, seizure with no status epilepticus, and fever with no seizure as a predictor for status epilepticus. This is a cross sectional study with 30 samples, consisted of 10 children with status epilepticus, 10 children with seizure, but no status epilepticus, and 10 children with fever, but no seizure. IL-8 and IL-4 levels were measured by ELISA. Statistical analyses were done by one-way ANOVA and Spearman's correlation test utilizing SPSS-23. The result showed a significant difference in IL-8 levels $(p=0.000)$, but not in IL-4 levels ( $p$ $=0.818$ ) for status epilepticus, seizure with no status epilepticus, and fever with no seizure. There was a significant difference in IL-4/L-8 ratio between groups $(p=0.000)$. There were significant correlation betweeen IL-8 level and status epilepticus, and between IL-4/LL-8 ratio and status epilepticus, but no significant correlation was found for IL-4 level.
\end{abstract}

Keywords:IL-8 level, IL-4 level, status epilepticus.

\footnotetext{
* Program Magister (S2) IImu Biomedik, Fakultas Kedokteran, Universitas Brawijaya

** Departemen Biokimia-Biomolekuler, Fakultas Kedokteran, Universitas Brawijaya

*** Departemen IImu Kesehatan Anak, Fakultas Kedokteran, Universitas Brawijaya
}

๒E-mail: percobaanhaykal@gmail.com 


\section{Pendahuluan}

Kejang merupakan suatu tanda adanya gangguan neurologis. Hampir $5 \%$ anak dengan usia kurang dari 16 tahun pernah mengalami kejang selama hidupnya. ${ }^{1}$ Mekanisme dasar terjadinya kejang adalah peningkatan aktifitas listrik yang berlebihan pada sel neuron dan timbulnya rangsangan pada sel neuron lain sehingga secara bersamaan melepas muatan listriknya. Hal ini diduga akibat berbagai kondisi, di antaranya adalah kemampuan membran sel sebagai pacemaker neuron dalam melepaskan muatan listrik yang berlebihan, berkurangnya kemampuan inhibisi asam gamma amino butirat (GABA) atau meningkatnya eksitasi sinaptik pada transmiter asam glutamat serta aspartat melalui jalur eksitasi secara berulang. Status epileptikus yakni kejang melebihi 30 menit atau adanya dua atau lebih kejang tanpa disertai pemulihan kesadaran di antara kejang yang terjadi akibat eksitasi berlebihan berlangsung terus menerus atau inhibisi yang tidak sempurna. ${ }^{2-4}$

Status epileptikus pada anak diperkirakan sekitar 10-58 per 100.000 anak. Status epileptikus lebih sering terjadi pada anak usia muda, terutama usia kurang dari 1 tahun dengan estimasi insiden 1 per 1000 bayi. ${ }^{4}$ Terjadinya status epileptikus dapat disebabkan oleh berbagai macam penyakit yang mendasari. Selain infeksi, kelainan primer pada sistem saraf pusat maupun kelainan metabolik juga dapat menyebabkan status epileptikus. ${ }^{5}$ Keradangan pada otak diperparah oleh pengeluaran mediator inflamasi yang dapat membangkitkan hipereksitabilitas selama proses kejang. Selain itu, peningkatan sitokin juga berpengaruh pada aktivasi sel endotel, astrosit dan mikroglia. Sitokin berperan pada proses infeksi dengan menginduksi demam, leukositosis, dan sintesis protein fase akut. Predisposisi genetik yang mendasar hal ini, bersamaan dengan asosiasi demam yang disertai kejang, menunjukkan kemungkinan keterlibatan gen untuk regulasi sitokin proinflamasi dan antiinflamasi yang berperan penting dalam proses terjadinya kejang. Beberapa sitokin yang berperan antara lain sitokin proinflamasi yaitu IL-8, IL-1 $\beta$, IL-6, TNF-a dan antiinflamasi IL-1ra, IL-4, dan IL10.6

IL-8 merupakan sitokin proinflamasi yang dilepaskan oleh sel fagosit dan berbagai sel pada jaringan yang dipicu oleh rangsangan inflamasi. IL-8 dilaporkan meningkat secara signifikan pada pasien epilepsi refrakter. ${ }^{6}$ Peningkatan biomarker inflamasi secara signifikan yaitu IL-6, IL-10, dan IL-8 juga terjadi pada pasien status epileptikus. $^{7}$

IL-4 memiliki peran sebagai antiinflamasi lokal maupun sistemik, karena berpotensi sebagai imunomodulator dan mampu menghambat produksi sitokin proinflamasi oleh monosit dan sel T. IL-4 memiliki pengaruh terhadap terjadi kejang pada individu. ${ }^{8}$

Kadar sitokin-sitokin yang berpengaruh pada proses aktivasi sel otak bisa dijadikan prediktor terjadinya status epileptikus. Namun, banyaknya jenis sitokin yang berperan menjadikan kendala pemilihan pemeriksaan. Untuk itu, banyak dilakukan penelitian yang mengevaluasi kadar sitokin di dalam darah yang nantinya dapat dijadikan prediktor status epileptikus. Pada penelitian ini, dilakukan analisis kadar IL-8 dan IL-4, serta rasio IL-4/IL-8 pada kelompok anak demam tanpa kejang, kejang tanpa status epileptikus, dan status epileptikus, yang belum pernah dilteliti

\section{Bahan dan Metode}

Penelitian ini merupakan observasional analitik menggunakan desain cross sectional yang membandingkan kadar IL-8 dan IL-4 anak dengan status epileptikus, kejang tanpa status epileptikus, dan demam tanpa kejang. 
Populasi dan Sampel

Sebanyak 30 sampel pasien didapatkan dari Instalasi Gawat Darurat (IGD) dan ruang rawat inap Departemen IImu Kesehatan Anak Rumah Sakit Saiful Anwar Malang, selama periode penelitian Januari 2017 sampai Januari 2018.

Sampel dijelaskan pada kriteria inklusi dan eksklusi sebagai berikut: A). Kriteria inklusi untuk kasus status epileptikus adalah pasien mengalami kejang selama 30 menit atau lebih, atau mengalami 2 atau lebih periode kejang dan di antara 2 kejang pasien tidak sadar. ${ }^{4}$ Pasien bersedia terlibat dalam penelitian dengan informed consent dari orang tua. Usia pasien 1 bulan sampai 18 tahun. Kriteria eksklusi untuk kasus status epileptikus adalah pasien dengan gizi buruk, pasien dengan keganasan, dan pasien penyakit autoimun. B). Kriteria inklusi untuk kasus kejang tanpa status epileptikus ${ }^{4}$ adalah pasien mengalami kejang kurang dari 30 menit dan tidak mengalami 2 atau lebih periode kejang yang di antara 2 kejang pasien tidak sadar. Pasien bersedia terlibat dalam penelitian dengan informed consent dari orang tua. Usia pasien 1 bulan sampai 18 tahun. Kriteria eksklusi untuk kasus kejang tanpa status epileptikus adalah pasien dengan gizi buruk, pasien dengan keganasan, dan pasien penyakit autoimun. C). Kriteria inklusi untuk kasus demam tanpa kejang yaitu pasien dengan febris tanpa menghiraukan penyebab febris. Tidak didapatkan kejang atau riwayat kejang pada pasien. Suhu tubuh $>38^{\circ} \mathrm{C}$. Pasien bersedia terlibat dalam penelitian dengan informed consent dari orang tua. Usia pasien 1 bulan sampai 18 tahun. Kriteria eksklusi untuk kasus demam tanpa kejang yaitu pasien dengan gizi buruk, pasien dengan keganasan, dan pasien penyakit autoimun.

\section{Sampel Darah}

Pengambilan dilakukan oleh paramedis yang terlatih. Volume darah yang diambil $2 \mathrm{ml}$ lalu dicampur dengan EDTA sebagai antikoagulan. Sampel darah segar disimpan dalam cool box dan dipertahankan suhunya 4 ${ }^{\circ} \mathrm{C}$ dan segera dikirim ke Laboratorium Biomedik, Fakultas Kedokteran Universitas Brawijaya. Sampel kemudian disentrifus pada kecepataan $1000 \mathrm{xg}$ selama 30 menit. Plasma dipindahkan ke dalam tabung eppendorf dan disimpan pada suhu $-20{ }^{\circ} \mathrm{C}$ atau $-80{ }^{\circ} \mathrm{C}$.

Pengukuran Kadar IL-8 dan IL-4 dengan Metode ELISA

Kadar IL-8 dan IL-4 dianalisis dengan metode enzyme-linked immunosorbent assay (ELISA). Pemeriksaan ELISA menggunakan kit Human IL-8 dan IL-4 Immunoassay (BioAssay, nomor katalog E0089 $\mathrm{Hu}$ dan E0092 Hu) sesuai dengan instruksi pada produk kit. Selanjutnya diukur absorbansi pada panjang gelombang $450 \mathrm{~nm}$ dengan metode spektrofotometri, lalu ditentukan kadarnya.

\section{Hasil}

\section{Karakteristik Subjek penelitian}

Penelitian ini melibatkan 30 subjek penelitian yang terbagi menjadi kelompok anak demam tanpa kejang sebagai kelompok kontrol ( $\mathrm{n}=10)$, kejang tanpa status epileptikus $(n=10)$, dan kelompok status epileptikus $(n=10)$. Karakteristik sampel tidak menunjukkan perbedaan yang signifikan pada sebaran usia, jenis kelamin, jumlah leukosit, dan kadar hemoglobin $(\mathrm{Hb})$ (Tabel 1).

\section{Kadar IL-8 pada Kelompok Status Epileptikus}

Pasien dengan status epileptikus memperlihatkan peningkatan kadar IL-8 dalam darah yang signifikan dibandingkan dengan kelompok demam tanpa kejang dan kelompok kejang tanpa status epileptikus $(p=$ $0,000<0,05)$ (Gambar 1). Kelompok kejang tanpa status epileptikus juga memperlihatkan 
peningkatan kadar IL-8 (78,29 ng/L), namun tidak sebesar kelompok dengan status epileptikus $(115,14 \mathrm{ng} / \mathrm{L})$. Bila melihat nilai $p$ pada uji post Hoc, perbandingan antara kelompok status epileptikus dan kelompok demam tanpa kejang mempunyai nilai yang lebih kecil dibandingan dengan kelompok kejang tanpa status epileptikus dan kelompok demam tanpa kejang. Hal ini menunjukan perbedaan yang signifikan antara kelompok status epileptikus dan kelompok demam tanpa kejang.

\section{Kadar IL-4 pada Kelompok Status Epileptikus}

Pada penelitian ini didapatkan rerata kadar IL-4 pada status epileptikus sebesar $731,24 \mathrm{ng} / \mathrm{L}$, kejang tanpa status epileptikus sebesar 719,37ng/L, dan demam tanpa kejang sebesar 712,63 ng/L. Analisis statistik menunjukka tidak ada perbedaan yang signifikan antar kelompok $(p=0,818>0,05)$ (Gambar 2). Selain itu, hasil uji Spearman menunjukkan tidak ada hubungan yang signifikan antara peningkatan kadar IL-4 dengan status epileptikus $(p=0,441>0,05)$.
Rasio IL-4/L-8 pada Kelompok Status Epileptikus

Jika melihat nilai IL-4 yang relatif sama antara kelompok kontrol dan status epileptikus, disertai peningkatan kadar IL-8 yang signifikan, maka dapat dihitung rasio IL4 dan IL-8 untuk meningkatkan nilai signifikansi prediksi kejadian status epileptikus (Gambar 3). Hasil rata-rata rasio IL-4/IL-8 kelompok status epileptikus merupakan yang terendah dengan nilai 6,97 jauh di bawah kelompok demam tanpa kejang yaitu 19,19 , sedangkan nilai kelompok kejang tanpa status epileptikus adalah 9,42.

Hubungan Status Epileptikus terhadap Kadar IL-8, IL-4, dan Rasio IL-4/IL-8

Hasil analisis uji Spearman menunjukan bahwa ada hubungan yang signifikan antara status epileptikus dengan kadar IL-8. Angka koefisien korelasi menggambarkan hubungan positif atau searah, dengan koefisien korelasi sebesar 0,850, dapat diartikan hubungan antara kelompok dengan kadar IL-8 berkorelasi tinggi karena berada pada rentang 0,80 hingga 1,00 . Sedangkan IL-4 tidak memiliki hubungan yang signifikan dengan status epileptikus $(p=0,441>0,05)$.

Tabel 1. Karakteristik sampel.

\begin{tabular}{ccccc}
\hline & \multicolumn{3}{c}{ Kelompok } & \\
\cline { 2 - 4 } & $\begin{array}{c}\text { Demam tanpa } \\
\text { kejang } \\
(n=10)\end{array}$ & $\begin{array}{c}\text { Kejang tanpa } \\
\text { status epileptikus } \\
(n=10)\end{array}$ & $\begin{array}{c}\text { Status } \\
\text { epileptikus } \\
(n=10)\end{array}$ & Nilai $p$ \\
\hline $\begin{array}{c}\text { Jenis kelamin } \\
\text { Laki-laki }\end{array}$ & 6 & 6 & 5 & 0,877 \\
Perempuan & 4 & 4 & 5 & \\
Usia (Bulan) & $21,00 \pm 13,275$ & $18,00 \pm 12,927$ & $20,50 \pm 9,156$ & 0,722 \\
Leukosit (103/u) & $11705 \pm 2789,7$ & $12448 \pm 1711,1$ & $14329 \pm 3596,1$ & 0,117 \\
Hb (gr/dl) & $10,27 \pm 0,787$ & $10,40 \pm 0,871$ & $10,39 \pm 0,858$ & 0,929 \\
\hline Keterangan: jika nilai $p<0,05$ berarti ada perbedaan yang bermakna dan jika nilai $p>0,05$ berarti tidak ada \\
\multicolumn{4}{r}{ perbedaan yang bermakna. }
\end{tabular}

Tabel 2. Hasil uji korelasi Spearman.

\begin{tabular}{lcc}
\hline \multicolumn{1}{c}{ Variabel } & Nilai $p$ & $\mathrm{R}$ \\
\hline IL-8 & 0,000 & 0,850 \\
IL-4 & 0,818 & 0,146 \\
IL-4/LL-8 & 0,000 & $-1,000$ \\
\hline
\end{tabular}




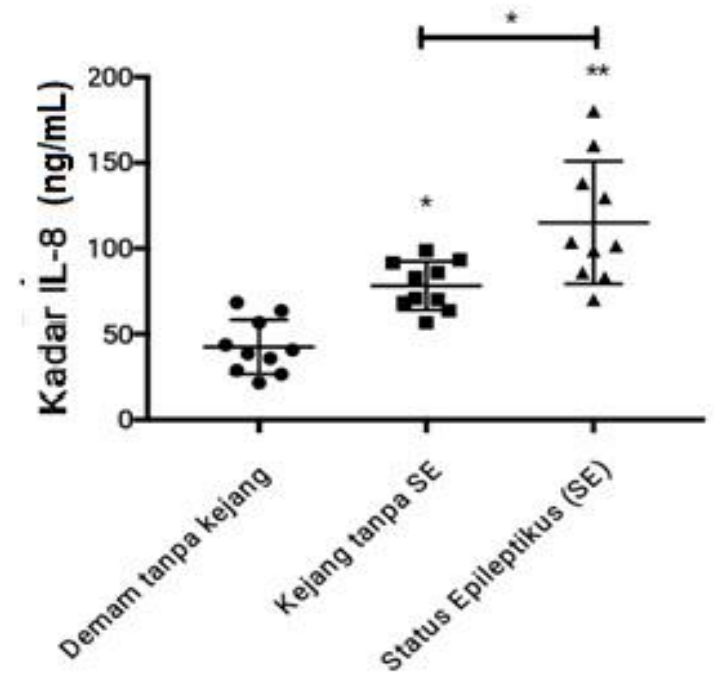

Gambar 1. Level IL-8 pada masing-masing kelompok.

Keterangan: Data dipresentasikan sebagai median dan interquartil range (25-75\%). Tiap titik mempresentasikan data individual. Beda signifikan didapatkan ketika $p<0,01\left(^{*}\right)$ atau $p<$ $\left.0,001{ }^{* *}\right)$.

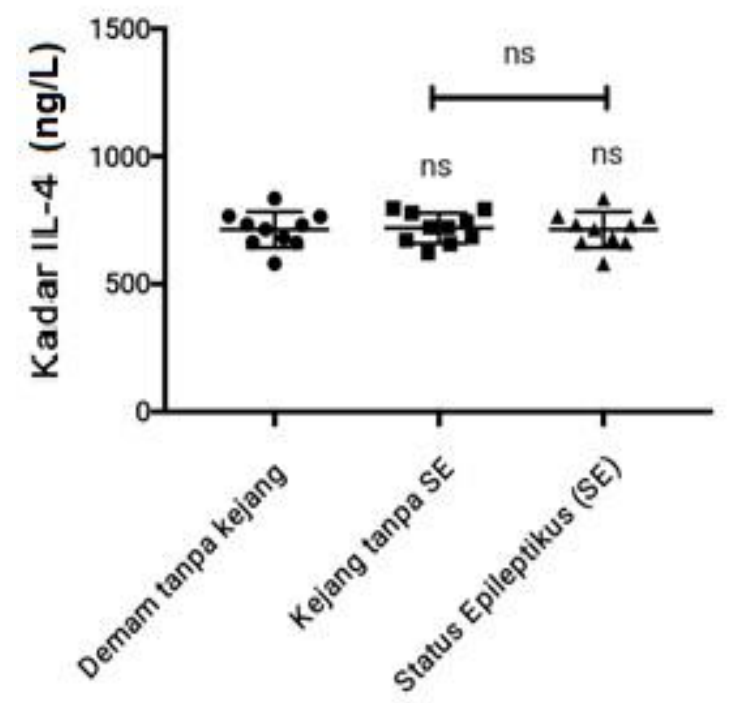

Gambar 2. Level IL-4 pada masing-masing kelompok.

Keterangan: Data dipresentasikan sebagai median dan interquartil range (25-75\%). Tiap titik mempresentasikan data individual. Tidak didapatkan beda signifikan antar kelompok. $n s=n o t$ significant. 


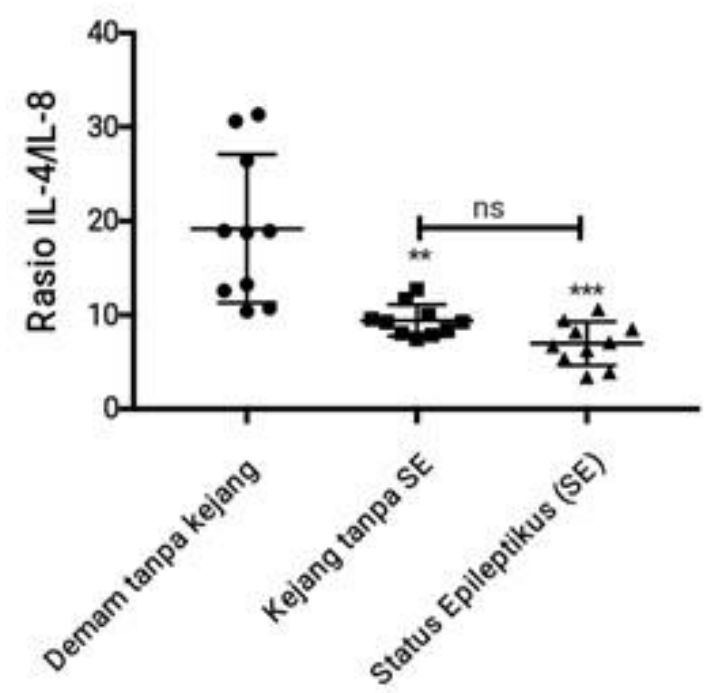

Gambar 3. Rasio IL-4/IL-8 pada masing-masing kelompok.

Keterangan: Data dipresentasikan sebagai median dan interquartil range (25-75\%). Tiap titik mempresentasikan data individual. Beda signifikan didapatkan ketika $p<0,001\left(^{* *}\right)$ atau $p<$ $\left.0,0001{ }^{* * *}\right)$.

\section{Pembahasan}

Penelitian ini melibatkan 30 sampel pasien yang terdiri dari 10 anak pada kelompok status epileptikus, 10 anak pada kelompok kejang tanpa status epileptikus, dan 10 anak demam tanpa kejang sebagai kelompok kontrol. Penelitian ini adalah penelitian observasional analitik menggunakan rancangan studi cross sectional dengan pengambilan sampel secara consecutive sampling. Pada karakteristik subjek penelitian tidak didapatkan perbedaan karakteristik yang signifikan baik usia, jenis kelamin, leukosit maupun $\mathrm{Hb}$ (Tabel 1). Sehingga dapat disimpulkan bahwa karakteristik subjek penelitian tidak berbeda.

Status epileptikus pada anak berkisar 10-58 per 100.000 per tahun pada anak usia 1-19 tahun. Insiden yang lebih tinggi telah dilaporkan pada anak berusia kurang dari 1 tahun, yaitu berkisar 135,2-156 per 100.000 anak/tahun. ${ }^{3,9}$ Kejang dikatakan lebih sering terjadi pada anak usia 17-34 bulan. ${ }^{10}$ Pada penelitian ini, usia rata-rata pasien status epileptikus adalah 20 bulan (1 tahun 8 bulan) sesuai dengan puncak terjadinya kejang pada anak.

Penelitian ini mendapatkan kadar IL-8 yang berbeda secara signifikan dengan nilai $p=0,000 \quad(<0,05)$. Kadar IL-8 tertinggi terdapat pada kelompok status epileptikus sebesar 115,14 ng/L diikuti kejang tanpa status epileptikus $78,29 \mathrm{ng} / \mathrm{L}$ dan demam tanpa kejang 42,53. Penelitian Bart et al., juga menunjukan terjadinya peninggkatan dari biomarker inflamasi secara signifikan yaitu IL-6, IL-10 dan IL-8 pada pasien status epileptikus. ${ }^{7}$ Hal ini disebabkan oleh keradangan pada otak yang diperparah oleh pengeluaran mediator inflamasi yang membangkitkan hipereksitabilitas selama proses kejang. Selain itu, peningkatan sitokin juga berpengaruh pada aktivasi sel endotel, astrosit dan mikroglia. ${ }^{6}$ Penelitian ini juga membuktikan adanya hubungan yang signifikan antara kadar IL-8 dengan status epileptikus ( $p=0,000<0,05)$, dengan hubungan yang kuat $(r=0,850)$.

Ada peningkatan kadar IL-4 pada status epileptikus sebesar 731,24 , diikuti 
kejang tanpa status epileptikus sebesar 719,37 , dan demam tanpa kejang sebesar 712,63 , meskipun tidak berbeda signifikan $(p=0,818>0,05)$. Penelitian ini juga menunjukan tidak didapatkan hubungan yang signifikan antara peningkatan kadar IL4 dengan status epileptikus. Hal ini terlihat dari uji Spearman didapatkan nilai $p=0,441$ $(>0,05)$. Sejalan dengan penelitian lain yang menyebutkan terjadi peningkatan kadar IL-4 pada pasien status epileptikus karena epilepsi. ${ }^{11}$ Namun, pada penelitian lain ditemukan pada 105 anak dengan kejang didapatkan kadar IL-4 yang rendah pada serum dengan kadar yang hampir sama dengan kelompok kontrol. ${ }^{12}$

Adanya perbedaan kadar IL-4 dapat disebabkan oleh berbagai faktor yaitu waktu pengambilan sampel yang hanya satu kali sehingga kadar antiinflamasi mungkin belum mengalami perubahan yang signifikan. Kadar IL-4 juga dapat mengalami peningkatan pada kasus atopi, sebagai akibat dari peningkatan kadar lgE yang merupakan respons dari paparan alergen. ${ }^{13}$ Infeksi parasit juga dapat mengiduksi pembentukan Th2. Adanya peningktatan Th2 menyebabkan akumulasi sel-sel basophil yang akan berpengaruh pada produksi IL-4. ${ }^{14}$ Dimungkinkan terdapat perbedaan kadar sitokin pada darah dan cairan serebrospinal pada pasien status epileptikus.

Sitokin dilaporkan mempengaruhi berbagai neurotransmitter sentral termasuk noradrenalin, 5-hidroxytriptamine (5-HT), gamma amino butyric acid (GABA) dan asetilkolin. ${ }^{15,16}$ Sitokin memiliki kontribusi pada kejadian kejang, sitokin proinflamasi di otak dapat memicu demam dan menginduksi transmisi di neuron. ${ }^{17}$ Peningkatan kadar proinflamasi tanpa disertai peningkatan antiinflamasi dapat menyebabkan ketidak seimbangan sitokin di dalam tubuh.

Sitokin proinflamasi dalam parenkim otak dan darah akan mengaktivasi kaskade signaling dan merusak sawar darah-otak yang mengawali suatu mekanisme kejang. Pada penelitian ini, didapatkan rasio IL-4/IL8 kelompok status epileptikus merupakan yang terendah dengan nilai 6,97 , jauh di bawah kelompok kontrol demam tanpa kejang dengan nilai 19,19 , sedangkan nilai kelompok kejang tanpa status epileptikus adalah 9,42 dengan hubungan yang signifikan $(r=1,000)$.

Pada penelitian ini, kondisi atopi maupun infeksi parasit belum dimasukkan sebagai kriteria eksklusi sehingga dapat mempengaruhi kadar IL-4. Pengambilan sampel hanya dilakukan pada darah tanpa dilakukan perbandingan dengan sampel cairan serebrospinal karena keterbatasan dalam pengambilan sampel.

\section{Kesimpulan}

Kesimpulan pada penelitian ini didapatkan kadar IL-8 serum lebih tinggi secara signifikan dan kadar IL-4 serum lebih tinggi namun tidak bermakna antara kelompok status epileptikus, kejang tanpa status epileptikus dan demam tanpa kejang. Didapatkan hubungan yang bermakna antara status epileptikus, kejang tanpa status epileptikus dan demam tanpa kejang dengan peningkatan kadar IL-8. Namun, tidak didapatkan hubungan yang bermakna dengan peningkatan kadar IL-4. Didapatkan rasio IL-4/IL-8 yang lebih rendah bermakna dengan hubungan yang kuat antara kelompok status epileptikus, kejang tanpa status epileptikus dan demam tanpa kejang.

\section{Saran}

Diperlukan metode penelitian yang lebih baik terutama faktor perancu, pengambilan sampel secara serial serta pengunaan sampel serebrospinal sebagai pembanding serum untuk pemeriksaan sitokin yang akan diteliti agar diperoleh hasil 
yang lebih baik. Penelitian lebih lanjut yang menghubungkan status epileptikus dengan sitokin lain perlu dilakukan untuk membuktikan peranan inflamasi pada patofisiologi status epileptikus pada anak.

\section{Daftar Pustaka}

1. Riviello JJ, Jr., Ashwal S, Hirtz D, Glauser T, Ballaban-Gil K, Kelley K, et al. Practice Parameter: Diagnostic Assessment of the Child with Status Epilepticus (An Evidence-Based Review): Report of the Quality Standards Subcommittee of the American Academy of Neurology and the Practice Committee of the Child Neurology Society. Neurology. 2006; 67(9):1542-50.

2. Chen JW, Wasterlain CG. Status Epilepticus: Pathophysiology and Management in Adults. Lancet Neurol. 2006; 5(3):246-56.

3. Nair pp, Kalita J, Misra UK. Status Epilepticus: Why, What and How. J Postgard Med. 2011; 57(3):242-52.

4. Goldstein JA, Chung MG. Status Epilepticus and Seizures. In: Abend NS, Helfaer MA (Editor). Pediatric Neurocritical Care. New York: Demos Medical. 2013. P. 117-138.

5. Bahera M, Rana S, Kanitkar K, Adhikari M. Status Epilepticus in Children. Medical Emergency. 2005; 61:174-178.

6. Youn $Y$, Kim S, Chung Y. Serial Examination of Serum IL-8, IL-10 and IL-1Ra Levels is Significant in Neonatal Seizures Induced by HypoxicIschaemic Encephalopathy. Scandinavian Journal of Immunology. 2012; 286-293.

7. Bart V, Evelin E, Kees P, Boss H, Braun K. Serum Inflammatory Mediators Correlate with Disease Activity in Electrical Status Epilepticus in Sleep (ESES) Syndrome. Epilepsia. 2016; 57(2):45-50.

8. Ameneh ZS, Samaneh S, Mahmoud RA. Association of IL-4 Single Nucleotide Polymorphisms with Febrile Seizures. Journal of Child Neurology. 2015; 30:423-428.

9. $\mathrm{Ng} \mathrm{YT}$, Maganti R. Status Epilepticus in Childhood. J Paediatr Child Health. 2013; 49(6):432-437.

10. Choi J, Min HJ, Shin JS. Increased Levels of HMGB1 and Proinflammatory Cytokines in Children with Febrile Seizures. Journal of Neuroinflammation. 2011; 8(135):1-9.

11. Sinha S, Patil S, Jayalekshmy V, Satishcandra P. Do Cytokines Have Any Role in Epilepsy?. Elsevier. 2008; 82: 171-176.

12. Makis A, Shipway D, Hatzimichael E, Galanakis E, Pshezhetskiy D, Chaliasos N, Stebbing J, Siamopoulou A. Cytokine and Adhesion Molecule Expression Evolves Between the Neutrophilic and Lymphocytic Phasesof Viral Meningitis. Journal of Interferon and Cytokine. 2010; 30(9):661- 665.

13. Choi $P$, Reiser H. IL-4: Role in Disease Anregulation of Production. Clin Exp Immunol. 1998; 113:317-319.

14. Min B, Prout M, Hu-Li J, Zhu J, Jankovic D, Morgan ES, Urban-Jr. JF, Dvorak AM, Finkelman FD, LeGros G, Paul WE. Basophil Produce IL-4 and Accumulate in Tissues after Infection with a Th2-Inducing Parasite. J Exp Med. 2004; 200(4):507-517.

15. Rao RS, Prakash A, Mehdi B. Role of Different Cytokines and Seizure Susceptibility: A New Dimension Towards Epilepsy Research. Indian J EXP Biol. 2009; 47:625-34.

16. Friedman $A$ and Dingledine $R$. Molecular Cascades that Mediate the Influence of Inflammation in Epilepsy. Epilepsia. 2011; 52:33-39. 
17. Kiarash R, Michael AG, Quentin JP. Contributions of Peripheral

Inflammation to Seizure Susceptibility:

Cytokines and Brain Excitability.

Epilepsy Research. 2009; 89:34-42. 